\title{
PENATAAN LINGKUNGAN BELAJAR TERPADU UNTUK MENINGKATKAN POTENSI KECERDASAN JAMAK ANAK
}

\author{
Rita Mariyana, Ocih Setiasih \\ Universitas Pendidikan Indonesia \\ rita_upi@yahoo.co.id, setiasih@upi.edu
}

\begin{abstract}
The aim of the research is to develop an integrated indoor and outdoor playground learning design to optimize multiple intelligences. Through research and development carried out two stages. The first stage, developing multiple intelligence instruments is needed to support the design of an integrated learning environment. The second stage, designing the setting design of integrated learning environment based on development stage. The results showed that the design of integrated learning environment management can optimize the multiple intelligence ofearly childhood.
\end{abstract}

Keywords: Learning Environment, Indoor, Outdoor Playground, Multiple Intelligences

\section{A. PENDAHULUAN}

Penelitian ini bertujuan untuk mengembangkan konsep dan penataan lingkungan belajar indoor dan outdoor playgound untuk pengembangan potensi kecerdasan jamak anak usia dini. Produk yang dihasilkan berupa desain seting lingkungan belajar indoor outdoor playgound terpadu untuk memaksimalkan potensi kecerdasan jamak anak usia dini. Asumsi potensi kecerdasan jamak (multiple intelligences) pada anak-anak muncul berdasarkan paradigma bahwa setiap anak memiliki potensi jenius. Setiap anak lahir dengan kemampuan tertentu. anak memiliki kekaguman, rasa ingin tahu, spontanitas, vitalitas, fleksibilitas, dan jauh lebih menyenangkan baginya. Anak usia dini akan langsung dikendalikan sistem yang kompleks dari simbol, otak brilian, kepribadian dan percepatan sensitif terhadap rangsangan apapun. Kewajiban orang tua di rumah dan guru di sekolah untuk memelihara kecerdasan masingmasing anak sejak dini. Kejeniusan alami anak harus dipelihara dan dipupuk secara optimal dengan bimbingan orang tua dan guru serta penyediaan lingkungan belajar yang kondusif untuk mengoptimalkan kecerdasan jamak anak. Lingkungan belajar anak usia dini sebaiknya menyediakan fasilitas bermain anak yang menjadikan anak bebas untuk bergerak, berkreasi, menjelajah termasuk melakukan berbagai manipulasi sehingga anak-anak mendapatkan beberapa perilaku baru dari aktivitasnya. Lingkungan belajar di dalam ruangan akan digunakan tempat belajar bagi anak-anak untuk mengasah berbagai potensinya. Hal yang menjadi perhatian setidaknya meliputi ukuran ruangan, keadaan lantai, dinding kelas, atap langit-langit dan lain-lain yang diperlukan dalam pengelolaan lingkungan belajar yang nyaman dan menyenangkan, (Mariyana, dkk.).

Kegiatan di lingkungan belajar luar ruangan tempat bermain anak (outdoor playground) merupakan bagian integral dari program pengembangan dan pembelajaran anak-anak. Lingkungan belajar di luar ruangan menguntungkan dan efektif membantu perkembangan anak-anak yang memiliki kecerdasan jamak yang bervariasi, maka lingkungan belajar outdoor playground harus menjadi bagian yang perlu ditata dengan baik dan serius. Pentingnya menyediakan lingkungan belajar yan kondusif untuk anak usia dini dapat merangsang dan mengembangkan 
potensi anak, khususnya potensi kecerdasan jamak yang dimiliki oleh masing-masing anak yang berbeda sehingga dengan mengembangkan model desain penataan seting lingkungan belajar indoor outdoor playground terpadu dapat meningkatkan potensi kecerdasan jamak yang dimiliki setiap anak.

Temuan penelitian Afoma R. Okudo Christy Omotuyole, (2014) menjelaskan bahwa lingkungan belajar anak prasekolah harus menyediakan fasilitas untuk kecerdasan bahasa anak-anak dan perkembangan keseluruhan dari konten dan gaya belajar setiap anak sehingga lingkungan belajar anak prasekolah harus sangat berbeda dari karakteristik orang dewasa. Temuan ini mengindikasikan bahwa lingkungan belajar anak usia dini harus berbeda dengan orang dewasa dan harus dapat mempasilitasi perkembangan dan optimalisasi kecerdasan jamak anak.

\section{B. KAJIAN LITERATUR}

Masa anak usia dini atau usia prasekolah adalah periode sensitif. Setiap anak sensitif untuk menerima rangsangan apapun, selama fungsi psikis dan fisik siap untuk menanggapi setiap stimulus yang diberikan oleh lingkungan. Dengan demikian, lingkungan sebagai unsur utama memberikan beberapa stimulus perlu ditangani secara serius. Diperlukan perencanaan dan seleksi khusus untuk memberikan lingkungan yang sesuai dan dibutuhkan oleh anak-anak. Akurasi dari lingkungan yang disediakan tidak akan berpengaruh pada proses dan hasil dari perilaku anak-anak, baik secara langsung maupun tidak langsung. Sebuah lingkungan belajar yang mampu mengembangkan berbagai perkembangan anak secara optimal jika dirancang secara apik dan baik. Akhirnya, dapat disimpulkan bahwa lingkungan belajar merupakan salah satu faktor kunci keberhasilan dalam membangun kemampuan dan perilaku anakanak dan mengembangkan potensi kecerdasan jamak anak. Implikasinya adalah bahwa lingkungan untuk anak-anak harus diberikan prioritas, terutama jika lingkungan tersebut adalah lingkungan belajar.

Memahami pengelolaan lingkungan belajar sangat penting, dan untuk menjadi bermakna, yang pertama perlu rumus untuk digabungkan adalah konsep lingkungan belajar. Dari kata "lingkungan" dan "belajar," dapat dirumuskan dalam hal lingkungan belajar, yang merupakan tempat atau suasana yang mempengaruhi proses perubahan perilaku manusia. Tentu saja manusia adalah anak sebagai subyek yang berada di lingkungan itu. Dari penjelasan tersebut dapat dipahami bahwa perubahan yang dihasilkan dari lingkungan dapat dirasakan dan relatif permanen. Semakin kuat pengaruh lingkungan, perubahan yang akan terjadi pada subjek yang diteliti diperkirakan akan lebih tinggi juga. Ini adalah besarnya pengaruh lingkungan terhadap perilaku belajar anak. Untuk itu akan sangat bijaksana, jika seseorang guru menampilkan peran lingkungan untuk perkembangan dan pertumbuhan individu, terutamaanak-anak.

1. Lingkungan Belajar Anak Usia Dini Periode usia PAUD atau prasekolah adalah masa peka. Anak sensitif untuk menerima segala rangsangan, yaitu pada masa fungsifungsi fisik dan psikis telah siap merespon segala rangsangan (stimulus) yang diberikan oleh lingkungan. Dengan demikian, lingkungan sebagai unsur yang mensuplai atau menyediakan sejumlah rangsangan perlu mendapatkan perhatian sungguhsungguh. Diperlukan perencanaan dan seleksi khusus agar dapat menyediakan lingkungan yang cocok dan diperlukan oleh anak. Ketepatan lingkungan yang disediakan akan memberi pengaruh pada proses dan hasil perilaku anak, baik secara langsung mau pun tidak langsung. 
Suatu lingkungan belajar yang benar mampu mengembangkan berbagai dimensi perkembangan anak secara optimal. Dapat disimpulkan bahwa lingkungan merupakan salah satu faktor penentu kunci keberhasilan dalam membangun kemampuan dan perilaku anak. Implikasinya adalah bahwa penyediaan lingkungan bagi anak hendaknya mendapat prioritas, apalagi jika lingkungan tersebut merupakan lingkungan belajar, (Mariyana, dkk.).

Pengertian lingkungan belajar secara bertahap. Agar lebih bermakna, rumusan pertama yang perlu dikombinasikan adalah konsep lingkungan belajar. Dari perpaduan kata "lingkungan" dan "belajar", secara sederhana dapat dirumuskan pengertian lingkungan belajar, yaitu suatu tempat atau suasana (keadaan) yang mempengaruhi proses perubahan tingkah laku manusia. Tentu manusia tersebut adalah pelajar sebagai subjek yang berada di lingkungan tersebut. Dari penjelasan tersebut dapat dilanjutkan bahwa perubahan-perubahan yang diakibatkan lingkungan dapat bersifat menetap dan relatif permanen. Semakin kuat pengaruh lingkungan tersebut, maka perubahan yang akan terjadi pada subyek belajar diprediksikan akan semakin tinggi pula. Inilah kehebatan pengaruh lingkungan terhadap perilaku seseorang. Untuk itu akan sangat tidak bijak, apabila seseorang menampikan saja peran lingkungan bagi perkembangan dan pertumbuhan individu, terutama anakanak. Bahwa lingkungan belajar merupakan sarana yang dengannya para pelajar dapat mencurahkan dirinya untuk beraktivitas, berkreasi, termasuk melakukan berbagai manipulasi banyak hal hingga mereka mendapatkan sejumlah perilaku baru dari kegiatannya itu. Dengan bahasa lain, lingkungan belajar dapat diartikan sebagai "laboratorium" atau tempat bagi anak untuk bereksplorasi, bereksperimen dan mengekspresikan diri untuk mendapatkan konsep dan informasi baru sebagai wujud dari hasil belajar. Jika pelajar itu adalah anak PAUD (Pendidikan Anak Usia Dini) atau prasekolah, maka lingkungan tersebut adalah lingkungan belajar yang diperuntukan bagi anak-anak usia PAUD atau prasekolah.

2. Lingkungan Belajar Indoor Untuk Anak UsiaDini

Mendapatkan ruangan kelas yang ideal, kita perlu memperhatikan pengaturan dan penataan ruangan kelasnya. Ruangan bermain indoor untuk anak biasanya berupa ruangan yang luas berbentuk persegi panjang, namun memiliki beberapa pembatas yang memisahkan satu area dengan area lainnya. Di setiap sudut ruangan juga biasanya disediakan tempat penyimpanan bahan-bahan yang dapat dipergunakan untuk beraktivitas.

Ruang kelas anak-anak yang lebih muda (sekitar 3-4 tahun) biasanya diatur dengan bentuk yang lebih sederhana. Keseluruhan aktivitas belajar terjadi di satu ruangan dan anak-anak dapat dengan leluasa duduk di lantai kelas. Beberapa gambar dan simbol pembelajaran dipasang untuk mendeskripsikan berbagai kegiatan yang terjadi di setiap sudut ruangan. Sebagai contoh, kegiatan membaca biasanya dilakukan di area belajar yang diberi nama "area bahasa", atau kegiatan menggambar di "area seni". Prinsipnya adalah bahwa kegiatankegiatan ini dilakukan pada area-area yang sudah dirancang sesuai dengan kebutuhan, (Mariyana, dkk.). Lingkungan dalam ruangan (indoor) sangat penting bagi anakanak. Lingkungan dan ruangan indoor harus akrab dan menghibur, mengurangi transisi dari suasana di rumah hingga pengaturan awal tahun sekolah. Hal ini melibatkan 
melengkapi lingkungan fisik dengan perabotan yang lembut, ruangan kecil dan ruang yang sepi. Pengaturan ruangan terbaik memudahkan transisi dengan melayani semua anak, (Beckley, 2012).

3. Lingkungan Belajar Outdoor Playground Untuk Anak Usia Dini

Kegiatan di luar ruangan merupakan suatu bagian integral dari program pendidikan anak usia dini. Bagi Froebel, taman bermain anak-anak itu bersifat "alamiah". Anak-anak memelihara kebun, membangun bendungan aliran air, memelihara binatang, dan melakukan permainan. Pada umumnya mereka melakukannya di luar ruangan atau di outdoor space. Selain anak menyukai udara bebas dan areanya yang luas, kegiatan di laur juga lebih banyak menyediakan berbagai fasilitas yang dapat dimanfaatkan anak untuk membantu perkembangannya.

Lingkungan belajar di luar kelas seyogyanya tidak hanya berperan sebagai tempat bermain melainkan juga sebagai tempat anak mengekspresikan keinginannya. Lingkungan ini merupakan tempat yang sangat menarik dimana anak-anak dapat tumbuh dan berkembang. Ketika anak-anak bermain di luar, mereka menunjukkan ketertarikan serta rasa ingin tahu yang tinggi. Karena lingkungan di luar kelas selalu penuh kejutan dan kaya akan perubahan. Di luar kelas anak-anak dapat mempelajari berbagai hal serta mengoptimalkan semua aspek perkembangannya. Guru-guru pun dapat membantu anak dalam meningkatkan pertumbuhan mereka melalui programprogram pembelajaran, yang dapat dievaluasi melalui pengamatan, atau pun berinteraksi langsung dengan anak.

Lingkungan belajar luar kelas (outdoor playground) yang terpadu yang juga merupakan salah satu cara yang dapat digunakan guru untuk mendorong kegiatan anak dalam keingintahuan, penyelidikan dan eksplorasi, memiliki sejumlah pengalaman sensual bagi anak-anak untuk mendorong anak menggunakan semua indra mereka, yang aman (Johnston, 2005) dalam (Beckley, 2012).

4. Optimalisasi Potensi Kecerdasan Jamak Anak Usia Dini

Melalui aktivitas di luar ruangan atau outdoor semua bagian perkembangan anak dapat ditingkatkan. Hal ini terjadi karena aktivitas outdoor melibatkan multi aspek perkembangan anak. Aktivitas outdoor lebih berperan dalam mengintegrasikan sensoris dan berbagai potensi yang dimiliki anak. Hal ini termasuk perkembangan fisik, keterampilan sosial dan pengetahuan budaya, serta perkembangan emosional dan intelektual.

Kecerdasan Jamak (Multiple Intellegences) merupakan istilah dalam kajian tentang kecerdasan yang diprakarsai oleh seorang pakar pendidikan Amerika Serikat bernama Howard Gardner (2004). Terdapat keragaman terjemahan tentang Multiple Intellegences ini, sebagian orang menerjemahkan dengan kecerdasan ganda, kecerdasan majemuk dan kecerdasan jamak. Dalam artikel ini yang dipergunakan sebagai terjemahan multiple intellegences adalah kecerdasan jamak.

Secara umum kecerdasan jamak pada anak yang dicetuskan oleh Howard Gardner (2004) adalah sebagai berikut ini:
a. KecerdasanLinguistik (Verbal);
b. Kecerdasan Logika-Matematika (Matematis-Logis);
c. Kecerdasan Spasial (Ruang);
d. Kecerdasan Kinestetik (Fisik dan Gerak);
e. Kecerdasan Musikal (Musik); 
f. Kecerdasan Interpersonal;

g. Kecerdasan Intrapersonal (Dalam Pribadi); dan

h. Kecerdasan Naturalis (Alam).

5. Mengenali Kecerdasan Jamak Anak Usia Dini

Mengembangkan sebuah profil dari kecerdasan jamak seseorang bukanlah hal yang sederhana. Tidak ada satu pun tes (kecerdasan) yang dapat menentukan potensi dan kualitas dari kecerdasankecerdasan seseorang. Tes-tes yang sudah terstandardisasi (saat ini), seperti yang sering dikemukakan oleh Howard Gardner (2004), hanya mengukur sebagian kecil dari keseluruhan spektrum kemampuan. Cara penilaian yang realistis dari kinerja orang dalam beraneka konteks jenis tugas dan kegiatan untuk menilai atau mengetahui kecerdasan jamak sesorang adalah dengan melalui sebuah pengalamanpengalaman terasosiasi antara satu kecerdasan dengan kecerdasan yang lain. Tentunya dibutuhkan waktu panjang untuk menelitinya, (Hoerr,2004).

Meskipun benar setiap anak dapat memiliki semua kecerdasan dan mampu mengembangkannya ke suatu tingkat yang cukup tinggi, anak-anak kelihatannya menunjukkan apa yang Howard Garner (2004) sebutkan sebagai kecenderungan terhadap kecerdasankecerdasan tertentu pada usia yang sangat muda. Pada saat anak masuk sekolah, anak mungkin telah menentukan cara-cara belajar yang lebih selaras dengan beberapa kecerdasan anak dibandingkan yang lain. Anak-anak yang menonjol kuat secara berpikir, menyukai membutuhkan linguistik dalam kata-kata membaca, menulis, menceritakan, bermain kata-kata, dsb. Bukubuku, kaset, kertas, diary, dialog, diskusi, debat, cerita-cerita, dsb. Logika matematis dengan menalar bereksperimen, menanyakan, mengatasi teka-teki logika, menghitung, dsb. Benda-benda yang bisa diselidiki dan dipikirkan, materi-materi ilmiah, yang dapat dikutak katik, kunjungankunjungan ke planetarium atau museum ilmiah. Ruangan gambargambar merancang, menggambar, menvisualisasikan, dsb. Seni, Lego, video, film, slide, permainan imajinasi, maze, puzzle, buku-buku ilustrasi, kunjungan-kunjungan ke museum seni. Tubuh fisik melalui sensasi-sensasi somatik tarian, berlari, melompat, membangun, menyentuh, dsb. Permainan peran, drama, gerakan, benda-benda yang bisa dibangun, olahraga dan permainan-permainan fisik, belajar langsung, dsb. Musik melalui iramairama dan melodi-melodi bernyanyi, bersiul, mengetuk menggunakan kaki dan mendengarkan, dsb Bernyanyi bersama-sama, mendatangi konser-konser, bermain musik di rumah dan sekolah, alat-alat sekolah, dsb. Interpersonal dengan memantulkan ide-ide mereka terhadap orang lain memimpin, berorganisasi, berelasi, memanipulasi, menengahi, dsb. Kawan-kawan, kelompok-kelompok permainan, perkumpulan sosial, acara komunitas, klub-klub, permur idan. Dalam pribadi jauh ke dalam dirinya membentuk tujuan-tujuan, bermeditasi, bermimpi, berdiam diri, berencana tempat-tempat rahasia, waktu sendirian, proyek-proyek pribadi, pilihan-pilihan. Kecerdasan alam dengan analogi yang ada di alam berada di alam berkeliaran, berhubungan, dan menyentuh tanah, air, hewan, dan angin, (Suyadi, 2014).

\section{METODOLOGI PENELITIAN}

Pendekatan penelitian yang
digunakan adalah Research and
Development karena bertujuan untuk
mengembangkan sebuah desain
penataan lingkungan belajar indoor dan
outdoor playgound terpadu yang dapat


memaksimalkan potensi kecerdasan jamak pada anak usia dini. Tahapan penelitian secara sederhana dikelompokan menjadi empat tahap kegiatan yaitu tahap studi pendahuluan, tahap perencanaan dan pengembangan model, uji coba dan revisi, serta validasi model. Untuk kegiatan pengembangan model digunakan pendekatan kualitatif dengan langkahlangkah: Merumuskan rencana pengembangan desain lingkungan indoor dan outdoor terpadu yang mampu meningkatkan potensi kecerdasan jamak anak usia dini; Mengembangkan desain awal lingkungan indoor outdoor terpadu yang mampu meningkatkan potensi kecerdasan jamak anak yang mencakup bentuk model, setting, pelaksanaan, dan evaluasi terhadap desain penataan lingkungan indoor outdoor terpadu yang telah dikembangkan.

\section{HASIL DAN PEMBAHASAN}

Hasil desain penataan lingkungan belajar indoor dan outdoor playground terpadu untuk meningkatkan potensi kecerdasan jamak anak usia dini (multiple intellegences) dapat dilihat pada gambar berikut ini.

\section{School Leyout}

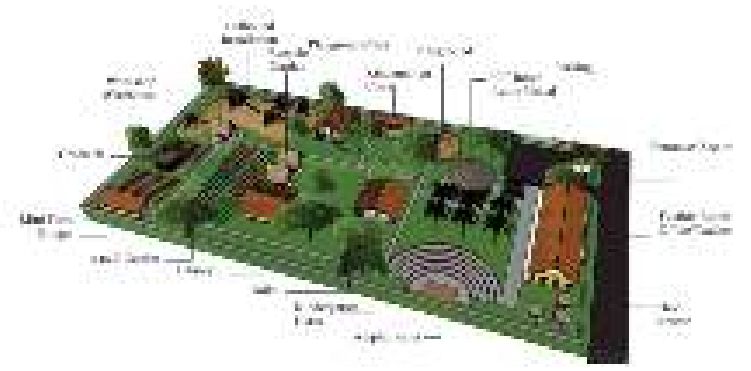

Gambar 1

Desain Setting Penataan Lingkungan Belajar Terpadu

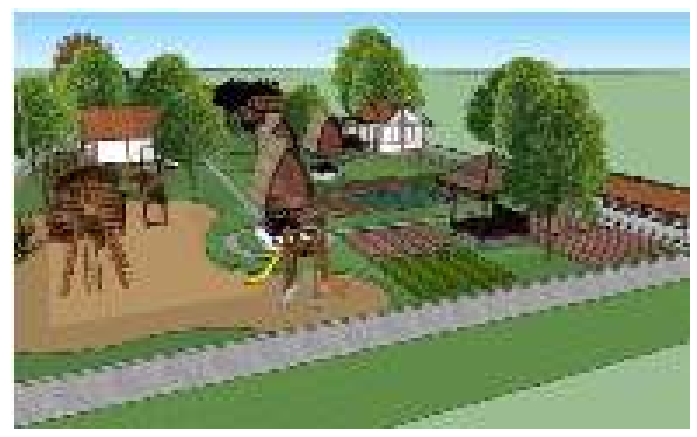

Gambar 2

Rancangan Lingkungan Belajar

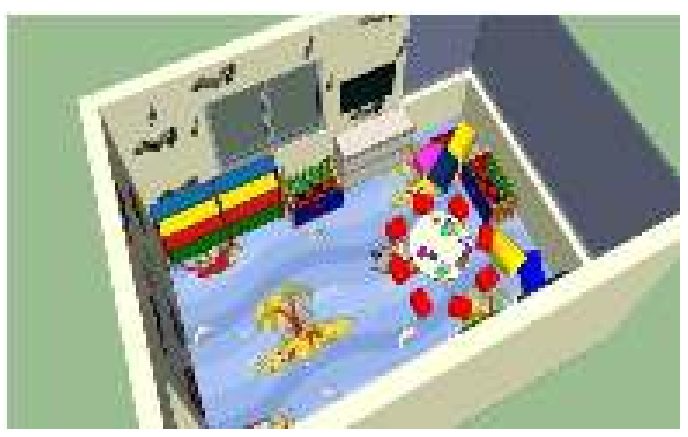

Gambar 3

Rancangan Ruang Belajar

Gambar 1 dan 2 diatas adalah rancangan lingkungan belajar terpadu. Gambar 2 adalah dalam kelas berbentuk rumah panggung berukuran $8 \mathrm{~m} \times 8 \mathrm{~m}$, dengan konsep tradisonal ramah lingkungan, menggunakan penerangan alami, dan memiliki ruangan yang sebagian terbuka. Berbagai aktivitas belajar mengajar yg berkaitan dengan metode kecerdasan majemuk dapat dilakukan, salah satunya dengan membuat display kelas yang dilakukan peserta didik dengan menggunakan material dari bahan bekas.

Perpustakaan sekolah merupakan salah satu fasilitas yang mampu merangsang dan meningkatkan kemampuan yang berkaitan dengan kecerdasan linguistik, melalui aneka kegiatan belajar mengajar yg menyenangkan, salah satunya melalui story telling atau membacakan sebuah buku, anak dilatih untuk menjadi pendengar yang baik, dan mampu menirukan atau menjelaskan apa di dengar anak.

Ruang ICT \& Audio Visual merupakan salah satu fasilitas yang mampu merangsang dan meningkatkan kemampuan yang berkaitan dengan kecerdasan logika dan kecerdasan Visual. Anak-anak dapat menyaksikan berbagai macam film dan permainan multimedia, yang dapat merangsang kreatifitas dan menambah ilmu 
pengetahuan dengan cara yang menyenangkan, seperti pengenalan science melalui film animasi atau belajar mengenal fungsi komputer melalui Games.

Green lab adalah sebuah kebun atau laboratorium alam, dimana para siswa belajar dan mengekplorasi serta berinteraksi dengan alam secara langsung, melalui aneka kegiatan belajar mengajar yang menyenangkan seperti belajar bercocok tanam, membuat kompos dan lain-lain. Aneka kegitan di Greenlab dapat menstimulus Anak-anak terutama pada usia 4 hingga 6 tahun, untuk meningkatkan kemampuan mengenali dan mengelompokan serta menggambarkan berbagai keistimewaan yang ada pada lingkungannya.

A to $\mathrm{Z}$ garden adalah sebuah fasilitas berbentuk kebun dengan koleksi aneka tumbuhan yang mewakili huruf alfabet mulai dari A sampai $Z$ seperti huruf A diwakili oleh tumbuhan Apel dan J diwakili oleh tumbuhan Jeruk dan seterusnya. Recycle garden dan Workshop adalah sebuah fasilitas workshop untuk mengolah atau mendaur ulang barang bekas menjadi aneka kerajinan, di Recycle Garden ini anak melakukan aneka aktivitas membuat kerajinan dari barang bekas dan melatih kecerdasan Visual. Amphiteater adalah Fasilitas tempat anak belajar aneka seni pertunjukan, mulai bernyanyi, bermain drama, membaca puisi, dan menjadi fasilitas untuk menunjukan kebolehannya di depan umum. Kegiatan pentas seni ini dapat memberikan nilai positif terhadap perkembangan anak usia dini, selain dapat memberikan perasaan senang, gembira dan menenangkan juga dapat dijadikan salah satu media alternatif untuk menanamkan nilai-nilai karakter yang dapat membangun kepribadian anak yang lebih baik di masa yang akan datang.

Outbound dan Playground adalah fasilitas untuk melatih mental dan fisik sekaligus sebagai sarana bermain. Kegiatan outbound sangat penting diterapkan kepada anak usia dini, selain mengurangi kejenuhan pada pembelajaran sehari-hari yang berada di dalam kelas, kegiatan ini juga bisa menjadikan tubuh menjadi sehat, karena kegiatan ini menuntut pesertanya untuk aktif bergerak dan dalam suasana ceria, gembira, dan menyenangkan, sehingga efeknya kepada fisik dan mental akan lebih terasa, yaitu efekpositif.

Hubungan antara kecerdasan dan proses belajar mengajar harus menjadi hal yang elemen mendasar dalam menghasilkan cara untuk mengoptimalkan potensi akademik anak yang lebih tinggi, kesuksesan pelajar dan pembelajaran sepanjang hayat (Özdemir, Güneysu \& Tekkaya, 2006). Hasil temuan Yalda Delgoshaei, Neda Delavari (2012) yang menerapkan pendekatan Multiple Intelligence di ruang kelas sebagai metode pendidikan menghasilkan peningkatan di kelima ranah pengembangan kognitif anak prasekolah dengan Signifikansi 99\%.

Ada banyak keuntungan menggunakan Multiple Intelligences dalam proses mentoring pembelajaran: proses mentoring menjadi lebih personal, guru awal menjadi lebih sadar akan kompetensi intelektual mereka; mereka juga menjadi pengamat murid mereka yang lebih baik dan dengan demikian mampu mempersonalisasikan proses belajar mengajar. (Roxana, Sorina Constantinescu, 2013).

\section{E. SIMPULAN REKOMENDASI}

DAN

Ada banyak cara menghasilkan suasana lingkungan belajar yang kondusif untuk mengoptimalkan kecerdasan jamak anak menjadi konsep dasar dalam proses pendidikan anak usia dini. Sepanjang melakukan hal tersebut, suatu filsafah yang menjadi tumpuannya adalah bahwa setiap anak atau murid adalah mereka yang dilayani dan diberikan suasana yang memungkinkan mereka bertumbuh dan berkembang. Anak tidak dicetak atau dipaksa menjadi sesuatu yang tidak cocok dengan kemampuan khas dan minat anak. Dengan kata lain, pendidik berfungsi 
sebagai bidan yang membantu proses kelahiran seorang bayi. Dengan sabar pendidik menolong proses tadi berjalan, serta dengan bijaksana dan waspada. Kebanggannya ialah apabila hasil dari proses tadi bertumbuh dan berkembang dengan baik dan optimal.

Adapun secara khusus kesimpulan dari hasil penelitian ini adalah:

1. Rumusan dan rancangan serta definisi suatu desain penataan lingkungan belajar indoor dan outdoor playgroud terpadu yang dapat meningkatkan potensi kecerdasan jamak anak usia dini adalah sebuah setting lingkungan belajar yang sengaja diciptakan untuk mendukung peningkatan potensi kecerdasan jamak anak usia dini.

2. Panduan desain setting penataan lingkungan belajar indoor dan outdoor playgound terpadu yang dapat meningkatkan potensi kecerdasan jamak anak usia dini adalah sebuah rencana yang sengaja dirumuskan untuk memandu proses pelaksanaan pembelajaran agar menunjang peningkatan kecerdasan jamak anak yang didukung dengan perangkat pembelajaran berupa Lesson Plan Activity (Aktifitas Rencana Pembelajaran) yaitu : Rencana Program Pembelajaran Harian (RPPH), Rencana Program Pembelajaran Mingguan (RPPM) dan Rencana Program Pembelajaran Tahunan (RPPT) yang satupadukan dalam sebuah proses pembelajaran di pendidikan anak usia dini.

\section{DAFTAR PUSTAKA}

Afoma R. Okudo Christy Omotuyole. (2014). Enhanced Learning Environment And Its Implications On The Pre-School Children's Language Performance. European Scientific Journal March 2014 edition vol.10, No.7 ISSN: 1857 7881(Print)e-ISSN1857-7431.
Beckley, Pat. (2012). Learning in Early Childhood. Sage Publication Ltd.

Brendon P Hyndman, Amanda Benson, Shahid Ullah and Amanda Telford. (2014). Evaluating the effects of the Lunchtime Enjoyment Activity and Play (LEAP) school playground intervention on children's quality of life, enjoyment and participation in physical activity. Hyndman et al. BMC Public Health 2014, 14:164 http://www.biomedcentral.com/ $1471-2458 / 14 / 164$.

Burcu Özdemir Beceren, 2010. Determining multiple intelligences pre-school children (4-6 age) in learning process. Elsevier. Procedia Social and Behavioral Sciences 2 (2010) 2473-2480. Available online atwww.sciencedirect.com.

Gardner, Howard. (2004). Frames of Mind The Theory of Multiple Intelligences. Basic Book: NewYork

Hoerr, Thomas. (2004). Becoming Multiple Intellegences Schools. Virgnia: ASCD.

Hoerr, Thomas. (2007). Buku Kerja Multiple Intellegences. Jakarta: Kaifa.

Hoerr, Thomas. (2010). Celebrating Every Learner, Activities and Strategies for Creating Multiple Intellegences Classrom. San Francisco CA Jakarta: JossyBass.

Mariyana, Rita, dkk. (2009). Pengelolaan Lingkungan Belajar. Jakarta: Prenada Media Group.

Suyadi. (2014). Teori Pembelajaran Anak Usia Dini Dalam Kajian 
PEDAGOGIA : Jurnal Ilmu Pendidikan

Neurosains. Bandung: Remaja

Rosda karya

Suyadi, Dahlia. (2014). Implementasi dan

Inovasi Kurikulum PAUD 2013

Program Pembelajaran Berbasis

Multiple Intellegences. Bandung:

RemajaRosdakarya.. 